\title{
LOUIS ADAMIČ IN DRUGA SVETOVNA VOJNA V AMERIŠKI IN SLOVENSKI HISTORIOGRAFIJI
}

\author{
Matjaž KLEMENČIČ', Milan MRĐENOVIĆ"
}

COBISS 1.02

\section{IZVLEČEK \\ Louis Adamič in druga svetovna vojna v ameriški in slovenski historiografiji}

Avtorja v članku predstavljata Adamičevo vlogo v drugi svetovni vojni, v kateri je deloval v okviru ameriških organizacij, kakršni sta bili Commom Council for American Unity in Vladna komisija za narodno obrambo. Pri tem se je zavzemal za upoštevanje etnične raznolikosti ameriškega prebivalstva pri aktiviranju v vojnih naporih ZDA. Adamič je bil tudi vodilni član organizacij ameriških južnoslovanskih izseljencev, kakršna sta bila Združeni odbor južnoslovanskih Američanov in Slovenski ameriški narodni svet. Ker novejša ameriška literatura delovanje jugoslovanskih Američanov med drugo svetovno vojno obravnava zlasti kot problem nacionalne varnosti ZDA, nam odkriva doslej še ne razkrito plat delovanja Louisa Adamiča.

KLJUČNE BESEDE: Louis Adamič, ZOJSA, FBI, komunizem, Jugoslavija

\section{ABSTRACT}

Louis Adamic and the Second World War in American and Slovenian Historiography The authors present Adamic's role during the Second World War. Adamic was active in various American organizations such as the Common Council for American Unity and the US government's National Defense Commission. He took the position that the ethnic diversity of the American population must be taken into account when activating it for the US military effort. He was also a leading member of organizations of American South Slavic immigrants, such as the United Committee of South-Slavic Americans and the Slovenian American National Council. More recent American literature on Yugoslav Americans during World War II deals with them predominantly as a problem of national security for the US, on the basis of which we discover new horizons of Adamic's activities during the Second World War.

KEY WORDS: Louis Adamic, UCSSA, FBI, communism, Yugoslavia

Dr. zgodovinskih znanosti, red. prof., Oddelek za zgodovino Filozofske fakultete Univerze v Mariboru, Koroška cesta 160, SI-2000 Maribor; matjaz.klemencic@um.si

\| Univ. dipl. zgodovinar, doktorski študent Ameriških študij na Oddelku za zgodovino Filozofske fakultete Univerze v Ljubljani, Aškerčeva 2, SI-1000 Ljubljana; milan.mr85@gmail.com 


\section{UVOD}

Namen pričujočega prispevka je na podlagi novejših virov na novo ovrednotiti vlogo Louisa Adamiča v drugi svetovni vojni. Adamič je $v$ tem obdobju deloval v ameriških organizacijah, kot sta bili Commom Council for American Unity in Vladna komisija za narodno obrambo. Zavzemal se je za upoštevanje etnične raznolikosti prebivalstva ZDA pri njegovem aktiviranju v vojnih naporih proti fašizmu. Bil je tudi vodilni član organizacij ameriških južnoslovanskih izseljencev, kakršni sta bili Združeni odbor južnoslovanskih Američanov in Slovenski ameriški narodni svet. Ker novejša ameriška znanstvena literatura jugoslovanske Američane med drugo svetovno vojno obravnava kot problem nacionalne varnosti ZDA, nam odkriva doslej še nerazkrito plat Adamičevega delovanja.

Članek sva napisala na podlagi klasične zgodovinske metodologije, ki zajema pregled in povzetek virov in literature, pri čemer sva upoštevala tako novejšo literaturo kot tudi na novo odkrite vire. Pomembno je omeniti, da so časopisni viri, ki odsevajo mnenja posameznih skupin o določenem dogajanju, v demokratičnih okoljih pomemben vir.

\section{POMEMBNEJŠA LITERATURA O LOUISU ADAMIČU}

Z Louisom Adamičem in njegovo politično dejavnostjo med drugo svetovno vojno smo se zgodovinarji ukvarjali zlasti ob obletnicah njegove smrti oziroma rojstva. Popularni članki o Adamiču so začeli izhajati izpod peresa novinarjev, kakršen je bil Bogdan Pogačnik, ki je leta 1981 v časniku Delo v več nadaljevanjih predstavil njegovo življenje in politično pot. V rubriki Književni listi' in Sobotni prilogi ${ }^{2}$ časnika Delo je Pogačnik skoraj vsak svoj prispevek začel z vprašanjem o Adamičevi skrivnostni smrti. Tako se je javnost začela pogosteje spraševati, ali je šlo v primeru njegove smrti za politično motivirani umor ali samomor? Vprašanje je seveda pomembno, vendar ne bi smelo zasenčiti Adamičevega ustvarjanja in delovanja v ZDA, zlasti njegovega političnega in družbenega angažiranja med drugo svetovno vojno v korist Slovenije in takratne Jugoslavije. Leta 1981 so ob 30-letnici njegove smrti na minesotski državni univerzi v St. Paulu, ZDA, v spomin nanj organizirali znanstveni simpozij. S pomočjo slovenskih izseljenskih organizacij so tega leta organizirali še tri prireditve v Clevelandu, New Yorku in Pittsburgu. V Ljubljani so septembra 1981 ob drugem simpoziju izdali poseben zbornik (Stanonik 1981: 3-9).

Pred simpozijem je Jerneja Petrič v knjigi Svetovi Louisa Adamiča skupaj s Henryjem Christianom objavila prevod virov, ki je istega leta kot Adamičev zbornik iz-

1 Pogačnik, Bogdan, »Portret pisatelja in politika Louisa Adamiča«, Delo, 9. april 1981: 13.

2 Pogačnik, Bogdan, »Vsaka njegova knjiga je bila akcija«, Sobotna priloga Dela, 19. september 1981: 26. 
šel pod naslovom Izbrana pisma Louisa Adamiča (Christian 1981: 9). V ZDA je Henry Christian že leta 1971 objavil bibliografijo Adamičevih del (Christian 1971: IX-XV). Opozorila bi še na enega pomembnega avtorja: Bogdana Novaka, ki je na minesotskem simpoziju predstavil referat, $v$ katerem je bil kritičen do Adamiča in njegovega delovanja; vsebino referata je po demokratizaciji Slovenije v dveh člankih objavil v Dveh domovinah: »Adamic and Yugoslavia during World War Il: The Slovene Catholic Response« (Novak 1994: 63-84) in »Louis Adamic's Work for the Official Recognition of Tito and the National Liberation Movement of Yugoslavia by the United States Government« (Novak 1998: 67-83).

Janja Žitnik z Inštituta za slovensko izseljenstvo ZRC SAZU je napisala trilogijo o zadnjem delu življenja Louisa Adamiča (Žitnik 1992; 1993; 1995). Po letu 1991 so se raziskovalci začeli bolj kritično ukvarjati z Adamičevo vlogo med drugo svetovno vojno. Tako je npr. Bogdan Novak napisal še knjigo o patru Kazimirju Zakrajšku (Novak 2004). Omenjena knjiga, ki je kritična do Adamičeve vloge, je lahko izšla šele po demokratičnih spremembah v Sloveniji po letu 1991. Pozneje je ameriški avtor Dan Shiffman napisal posebno knjigo, ki je bila v slovenščino prevedena z naslovom Korenine multikulturalizma: Delo Louisa Adamiča. Knjiga obravnava Adamičev prispevek k multietničnim in multikulturnim študijam za sodobno družbo 21. stoletja (Shiffman 2005).

Glede interpretacije Adamičeve vloge med drugo svetovno vojno moramo objektivno razločevati med dvema razdobjema. Enega pred letom 1991 in drugega po njem. Leta 1983 je Matjaž Klemenčič obranil svojo doktorsko disertacijo s tematiko ameriških Slovencev v drugi svetovni vojni in jo pozneje tudi objavil (Klemenčič 1987).

Leta 2007 je izšla knjiga avtorice Lorraine M. Lees, specialistke za diplomatske odnose med ZDA in Jugoslavijo, v kateri obravnava jugoslovansko ameriško skupnost med drugo svetovno vojno. Knjiga problematiko obdeluje s povsem drugačnega stališča, kot jo obravnavamo zgodovinarji etničnih skupnosti. Proučevalce etničnih skupnosti $v$ ZDA zanimata tudi odzivnost teh skupnosti na dogajanje $v$ stari domovini in njihova stopnja prizadetosti v zvezi s tem dogajanjem. Zgodovinarji in drugi raziskovalci za to najprej uporabimo vire, ki so jih ustvarile priseljenske skupnosti, kot so npr. etnično časopisje, korespondenca pomembnih voditeljev in njihova poročila. Prav tako so pomembne interakcije voditeljev priseljenskih skupnosti z vladnimi službami in s takratnimi politiki. Lees pa v svoji knjigi obravnava skoraj izključno odzive posebnih vladnih služb, zlasti varnostnih, ki so sledile dejavnostim jugoslovanskih priseljenskih skupnosti. Avtorico so zanimala predvsem stališča ameriške države do dejavnosti posameznih priseljenskih organizacij, deloma tudi tistih, ki so bile na ameriških tleh organizirane $z$ namenom odzivanja na dogajanja $v$ stari domovini. Lorraine M. Lees se je torej spraševala, kakšen vpliv je imela dejavnost teh skupnosti in organizacij na ameriško državno varnost. Zanimivo je, kako je že med prvo svetovno vojno ameriška vlada organizirano sledila dejavnostim raznih skupnosti, še zlasti tistih, katerih domovine so bile $v$ vojni z ZDA, to pa so bile zlasti nemške in avstrijske priseljenske skupnosti (Lees 2007: 7; Hazemali, Friš 2018: 899-922; Klemenčič, Šeruga 2019: 29-34). 
Ameriške varnostne službe zelo dolgo niso razločevale med slovensko govorečimi osebami oziroma osebami slovenskega porekla iz Avstro-Ogrske, ki je bila z ZDA $\checkmark$ vojni, in nemško govorečimi habsburškimi podaniki. Ustrezne ameriške službe so med prvo svetovno vojno kmalu spoznale, da je treba osebe in skupine razločevati ne le po državi rojstva, ampak tudi po etnični pripadnosti. Tako so jih začela zanimati stališča različnih etničnih skupnosti do politike ZDA. Zanimivo, da je med prvo svetovno vojno takšnim skupnostim sledil poseben oddelek Ministrstva za pravosodje, ki ga je vodil poznejši dolgoletni direktor FBI, Edgar J. Hoover. Poleg tega je bila med prvo svetovno vojno za spremljanje ameriških etničnih skupnosti v ZDA odgovorna tudi posebna vojaška obveščevalna služba (Jeffreys Jones 2007: 65-70).

\section{ADAMIČEVO POLITIČNO DELOVANJE PRED KONGRESOM SANS}

Američani so se pred vstopom ZDA v drugo svetovno vojno dobro zavedali problema obstoja raznih etničnih skupnosti na svojih tleh, zato so se dobro pripravili na njihovo sledenje. Jugoslovanski Američani so bili po mnenju Lorraine M. Lees klasičen primer razklane skupnosti, $v$ kateri so odsevali dogodki na tleh Kraljevine Jugoslavije med drugo svetovno vojno. Tako naj bi različne etnične skupnosti predstavljale posebno stopnjo nevarnosti za ameriško državo, saj naj bi se med njimi skrivali komunistični oziroma fašistični simpatizerji (Lees 2007: 54). Organizacije, ki jim je pripadal in jih med drugo svetovno vojno pomagal organizirati tudi Louis Adamič, so s stališča ameriške državne varnosti po ameriških kriterijih predstavljale t. i. »komunistično nevarnost«. To dokazujejo tudi številni danes dostopni dokumenti FBI.

Srbsko izseljensko skupnost so med drugo svetovno vojno predstavljale najrazličnejše organizacije. Podpiral jih je Srpski narodni savez (Serb National Federation), srbska bratska podporna organizacija, ki je izdajala svoje glasilo Srbobran. Srpski narodni savez in njegovo glasilo sta za ZDA takrat predstavljala srbsko nacionalistično nevarnost. V zaključku dela avtorica Lorraine $M$. Lees ugotavlja, da so srbske organizacije v bistvu ohranile duh srbskega nacionalizma, ki je vel iz delovanja teh organizacij, da je preživel in se po razpadu Jugoslavije leta 1990 ponovno okrepil. Zanimivo, da v zvezi s tem avtorica omenja tudi dejavnosti poznejše zagovornice srbskih interesov v Kongresu ZDA na razpotju devetdesetih let 20. stoletja, kongresnice iz Marylanda, Helen Delich Bentley. (Prav tam: 210; o njeni dejavnosti glej Klemenčič 2011: 37-53)

Zanimivo, kako se je Adamičeve dejavnosti v najboljšem pregledu zgodovine FBI dotaknila tudi knjiga The FBI: A History avtorja Rhodrija Jeffreysa Jonesa, v kateri avtor omenja Adamičevo knjigo Dinamit, ki obravnava zgodovino organiziranosti ameriškega delavstva $\vee$ ZDA, in sicer v negativnem smislu, saj naj bi knjiga spodbujala radikalnost ameriških delavcev (Jeffreys Jones 2007: 88).

Rooseveltova administracija je v kritičnem obdobju, ko je Adolf Hitler v prvi polovici leta 1941 v Evropi postajal vse bolj vpliven, poskušala storiti vse, da bi Jugoslavijo 
ohranila neodvisno in nevtralno. Vendar zaradi posebnega geostrateškega položaja Jugoslavije na Balkanu politika izogibanja sodelovanju z Nemčijo ni bila mogoča. Jugoslavija je zaradi pritiskov Berlina kmalu klonila. Po vojaškem udaru, ki je pripeljal državo v vojno z Nemčijo, se je Jugoslavija znašla na strani zaveznikov, v državi pa se je razmahnilo odporniško gibanje. $V$ ZDA se je začela bitka za javno mnenje, katera uporniška stran bo uživala največje simpatije. Četniška ali partizanska? V podporo četnikom je jugoslovanska vlada v izgnanstvu ustanovila »informacijski center v New Yorku«, v katerem je delovalo kar nekaj jugoslovanskih ministrov. Čeprav so Američani poleti 1943 svoje opazovalce poslali tako četnikom kot partizanom, so še vedno podpirali četnike Draže Mihailovića (Lees 2007: 131-132), medtem ko so Titove partizane razglašali za komunistične borce (Klemenčič 1987: 143-157). Na drugi strani javnega mnenja v ZDA so stali liberalno in socialistično usmerjeni izseljenci, ki so želeli videti drugačno in federativno Jugoslavijo brez kralja na čelu države. Njihov najvidnejši predstavnik je bil Louis Adamič.

Ameriški vojni opazovalci so glede vojaškega stanja v Jugoslaviji poročali, da so za zaveznike tudi četniki bojevali učinkovite vojaške operacije »velikega strateškega pomena«. Dejstvo je, da je zadnji ameriški vojni opazovalec zapustil štab Draže Mihailovića šele 11. decembra 1944, ko je Titova vojska s pomočjo Rdeče armade že osvobodila vsaj polovico Jugoslavije (prav tam: 152). Naj ob tem omeniva, da je pri odločitvah o pošiljanju pomoči Titovim partizanom v ZDA najpomembnejšo vlogo odigral Louis Adamič, ko je s svojim pisanjem v časopisih, zlasti s svojim znamenitim prispevkom $v$ The Saturday Evening Post zapisal, kako se $v$ Jugoslaviji proti okupatorjem dejansko bojujejo samo Titovi partizani. ${ }^{3}$ Ko je FBI v tem času sledil Louisu Adamiču in ga razglašal za »komunističnega sopotnika«, se je ta z Alanom Cranstonom, šefom oddelka za tujejezične skupnosti pri Office of War Information, pogovarjal o propagandi med izseljenci, da bi jih pridobili za kupovanje ameriških vojnih obveznic, s katerimi so med drugo svetovno vojno financirali vojsko. Ameriška vlada je še v začetku leta 1945 menila, da bi bilo pošiljanje orožja samo partizanom velika nepravičnost do drugih zaslužnih skupin jugoslovanskih množic, katerih edini prestopek je bilo nasprotovanje »partizanskemu gospostvu« (Lees 2007: 9, 108, 149, 160; Klemenčič 1987: 194).

Še pred napadom sil osi na Kraljevino Jugoslavijo, 6. aprila 1941, so Slovenci v ZDA pozivali vlado, naj se čimprej vključi v vojno. Po drugi strani je Adamič že leta 1939 poseben poziv naslovil na slovenske bratske podporne organizacije, naj pomagajo z zbiranjem sredstev, $s$ katerimi bi na varno $v$ ZDA pripeljali znane slovenske kulturnike. Pobuda je zaradi premajhnega zanimanja bratskih podpornih organizacij v ZDA usahnila. ${ }^{4}$ Adamič je bil še pred vstopom ZDA v vojno med vodilnimi člani Commom Council for American Unity (CCAU), organizacije, ki se je zavzemala za socialne in etnične pravice ameriških priseljencev. Julija 1940 je postal

3 »Balkan Mystery Man«, The Saturday Evening Post, 19. december 1942: 20-21.

4 »Slovenskim podpornim organizacijam«, Nova doba, 26. april 1939: 2. 
svetovalec pri vladni komisiji za narodno obrambo, ki je bila ustanovljena pri Narodnoobrambnem svetu ZDA. Na Adamičevo pobudo je omenjena komisija že v začetku julija 1940 pozvala k vključevanju vseh Američanov, ne glede na njihovo poreklo, v obrambni program države. ${ }^{5}$ Adamič je tako 3. aprila 1941 v sodelovanju s CCAU poudaril, da so se $v$ ZDA začeli prepozno zavedati pozitivnega pomena raznovrstnosti njenega prebivalstva. Adamič je že takrat uspešno lobiral pri visoki politiki, osebno je namreč poznal soprogo tedanjega ameriškega predsednika, Eleanor Roosevelt (Klemenčič 1987: 161).

Druga svetovna vojna je ameriške Slovence speljala v dve vrsti delovanja. Prvo je bilo osredotočeno na zbiranje politične podpore, drugo se je usmerjalo na zbiranje materialnih sredstev za pomoč stari domovini. Obe dejavnosti sta se ves čas prepletali. Ker razmere za politično podporo še niso dozorele, so se o tem sprva okvirno pogovarjali le na sejah Jugoslovanskega pomožnega odbora - Slovenske sekcije (JPO-SS). Svoje politične pobude so naslavljali na slovenske člane kraljevske vlade, ki so delovali v Jugoslovanskem informativnem centru v New Yorku. Akcije zbiranja sredstev za pomoč razrušeni domovini je sprva vodil Jugoslovanski pomožni odbor - Slovenska sekcija, nato pa Slovensko-ameriški narodni svet (SANS). Pri tem naj poudariva, da so na začetku sodelovali celo s Konstantinom Fotićem, jugoslovanskim poslanikom v ZDA, ki je takoj 7. aprila 1941 poslal vsem slovenskim, hrvaškim in srbskim organizacijam svoje pozive za zbiranje pomoči Jugoslaviji. Nekaj dni po tem je Fotić še enkrat zaprosil izseljenske organizacije, naj pri zbiranju sredstev pomagajo preko ameriškega Rdečega križa. Verjetno je do takšne pobude prišlo zaradi pritiskov ameriške vlade. Fotićeva akcija v glavnem ni uspela, saj mu nobena izseljenska organizacija v ZDA ni želela prepustiti nadzora nad zbiranjem svojega denarja ${ }^{6}$ (Fotitch 1948: 107). Zaradi tega so 19. aprila 1941 v Chicagu predstavniki ameriških Slovencev na predlog Ameriške bratske zveze ustanovili svoj prej omenjeni Jugoslovanski pomožni odbor. Za predsednika organizacije so izbrali Vincenta Cainkarja, glavnega predsednika Slovenske narodne podporne jednote (SNPJ).?

Zanimivo je, da je JPO-SS denar z namenom pomoči stari domovini nameraval poslati $v$ staro domovino šele po vojni, ko bi se politične razmere $v$ stari domovini razjasnile. Maja 1941 je nastala še pomožna akcija organizacije Zveze slovenskih župnij, ki je imela namen zbrati denar za takojšnjo pomoč stari domovini. Voditelja akcije sta bila patra Kazimir Zakrajšek in Bernard Ambrožič, ki sta leta 1941 po zavitih poteh pripotovala v ZDA. Pater Ambrožič je že decembra 1941 poročal, da je v Slovenijo prišlo 40 tisoč dolarjev njihove pomoči, pozneje so poslali še več. Adamič patru Zakrajšku nikoli ni zaupal (Klemenčič 1987: 166-171; Friš 2001: 267-280). ${ }^{8}$

Jugoslovanska vlada v izgnanstvu je septembra 1941 sklenila, da bo v ZDA napotila posebno vladno delegacijo, ki bo obiskala izseljence in ocenila njihov položaj ter

5 »Interview Louisa Adamiča«, Nova doba, 7. avgust 1940: 7.

6 »Pomožna akcija za Jugoslovane«, Prosveta, 11. april 1941: 1.

7 »Ameriškim Slovencem«, Enakopravnost, 23. april 1941: 1.

8 »Poročilo svete stolice o pomoči Sloveniji«, Amerikanski Slovenec, 6. december 1941: 3. 
možnosti za skupno sodelovanje. Vladno delegacijo so sestavljali srbski, hrvaški in slovenski predstavniki. ${ }^{9}$ Prišlo je tudi do kratkega sodelovanja posameznih ministrov, ki so se udeleževali sej jugoslovanskega pomožnega odbora, vendar so se ameriški Slovenci na koncu raje odločili, da bodo za politično delovanje med ameriškimi Slovenci ustanovili svojo posebno organizacijo. Cilja organizacije sta bila podpora neusmiljenemu boju zoper okupatorje in zagovor politične združitve slovenskega naroda v eno celoto, seveda v okviru države Jugoslavije (Hudomalj 2004: 121-130). Že takrat se je pojavilo vprašanje, komu naj združena Slovenija pripade: srednjeevropski federaciji ali Jugoslaviji? Ameriški Slovenci so se zavzeli za slednjo, torej federativno Jugoslavijo, katere del naj bi bila združena Slovenija. Takrat še ni bilo jasno niti, kakšna bo povojna politična ureditev Evrope, niti, kakšna bo ureditev povojne Jugoslavije. Jasno je bilo samo to, da je bila večina ameriških Slovencev bolj naklonjena republikanski državni ureditvi kot monarhiji, zato so se njihova razmišljanja o prihodnosti Jugoslavije že razhajala (Klemenčič 1987: 171, 210).

Na sestanku JPO 15. novembra 1941 izvoljeni odbor je nato pripravil vse potrebno za organizacijo prvega slovenskega narodnega kongresa. ${ }^{10}$ Tudi pater Kazimir Zakrajšek je v tem času povečal svoje aktivnosti in do leta 1942 napisal knjigo Ko smo šli v morje bridkosti, v kateri je zagovarjal demokratično in federativno preureditev Jugoslavije (Zakrajšek 1942: 171). Obenem je bil naklonjen tudi ideji podonavske katoliške federacije, ki jo je zagovarjal Otto von Habsburg, sin zadnjega avstro-ogrskega cesarja Karla. Zato so mnogi ameriški Slovenci postali zadržani do njegovega delovanja. Čeprav je pater Zakrajšek poudaril, da je bila zanj podonavska federacija zadnja rešitev, je kljub temu pri »levo usmerjenih« Slovencih vzbujal nelagodne sume in nezaupanje. Takrat je med katoliki v ZDA prevladovalo mnenje, da bo zaradi nesoglasji, ki so nastali med pravoslavnimi Srbi in katoliškimi Hrvati, Jugoslavija prenehala obstajati (Klemenčič 1987: 176).

Pater Zakrajšek naj bi bil med drugim naklonjen tudi republikanski preureditvi povojne Jugoslavije. V svojem pismu, v katerem naznanja svoj odstop z mesta tajnika SANS, se je predstavil kot demokrat in ne monarhist. Vedno je poudarjal, da bi morali o prihodnji ureditvi Jugoslavije ljudje sami odločati na svobodnih volitvah (Friš 1995: 180). V tem času se je začelo postavljati pomembno vprašanje, kdo bo vodil politično akcijo ameriških Slovencev? Ameriški državljani slovenskega porekla ali predstavniki begunske vlade $v$ izgnanstvu? Pater Zakrajšek je za vodjo predlagal slovenskega ministra begunske vlade, Franca Snoja (Hudomalj 2004: 121-130). Ameriški Slovenci so se na koncu odločili, da bodo politično akcijo v ZDA vodili slovenski izseljenci $z$ ameriškim državljanstvom. Tako sta poskusa begunske vlade $v$ Londonu kot tudi pomožne akcije katoliških duhovnikov, da bi pridobili jugoslovanske izseljence na svojo stran, dokončno propadla. Glavno pobudo je prevzel Louis Adamič (Novak 1994: 67).

9 »Novejše vesti iz domovine«, Amerikanski Slovenec, 26. september 1941: 3.

10 "Slovenski narodni kongres v Ameriki«, Amerikanski Slovenec, 27. november 1941: 3. 
Po napadu na Pearl Harbor 7. decembra 1941 je državni sekretar Cordell Hull izjavil, naj bi posamične akcije etničnih skupnosti v ZDA postale nezaželene in da bi morali vsi enotno podpreti ameriško ljudstvo. Adamič je preveril trditev in se sestal z izvršnim pomočnikom državnega sekretarja Adolfa Berleta, Heraldom B. Hoskinsom, ki je bil v State Departmentu odgovoren za stike z voditelji priseljenskih skupnosti. Na konkretno vprašanje mu je Hoskins odgovoril, da kongresa ameriških Slovencev ni treba odložiti, vendar ga morajo organizirati ameriški Slovenci, ne pa člani tuje vlade, kot je jugoslovanska vlada v izgnanstvu. ${ }^{11}$ Adamič je nato prevzel pobudo in 4. januarja 1942 sklical sestanek vseh predsednikov slovenskih organizacij v Clevelandu. Adamič je že prej, 6. avgusta 1941, podpredsedniku jugoslovanske vlade v izgnanstvu, dr. Mihi Kreku, poslal osnutek svojega programa o političnem delu »nove Jugoslavije.$^{12} \mathrm{~V}$ programu je zapisal, da mora biti Jugoslavija obnovljena v svojih predvojnih mejah, poleg tega naj bi se ji priključila tudi tista ozemlja, na katerih so večinoma živeli Hrvati in Slovenci. Na federalni osnovi ustanovljena država naj bi Srbom, Hrvatom in Slovencem omogočala največjo možno avtonomijo. Država bi bila utemeljena na demokratičnih vrednotah, splošni volilni pravici, svobodi govora in vere, tiska, javnih zborovanj, kolektivnih sindikalnih pogajanj in kmečkih zadrug. Program je predvideval združitev jugovzhodnoevropskih držav v nekakšno federacijo. To je bilo v skladu z Adamičevo idejo o evropski federaciji, o kateri je pisal v knjigi Two Way Passage (Adamic 1941: 74).

Na slabo razpoloženje ameriških Srbov je vplivala ustanovitev NDH, kar je Konstantin Fotić spretno zlorabljal za svoje nediplomatske napade na Hrvate in posredno tudi za napade na idejo o federativni Jugoslaviji. Fotić je zagovarjal idejo »Velike Srbije«. Franc Snoj, ki je bil tedaj v Clevelandu, je navezal stike s predsednikom Kranjske slovenske katoliške jednote - KSKJ, Antonom Grdinom, in dr. Petrom Malijem (Mally), častnim konzulom Kraljevine Jugoslavije v Clevelandu. Osmega februarja 1942 so ameriški Slovenci zborovali v narodnem domu v Clevelandu in ob tem govorili o trpljenju jugoslovanskih narodov pod fašisti in nacisti, hkrati hvalili odporniško gibanje četnikov Draže Mihailovića in zahtevali pravičnejšo povojno ureditev Jugoslavije (Klemenčič 1987: 181, 185).

Ameriški Slovenci so s teh zborovanj pošiljali pisma, v katerih so pozdravljali kralja Petra II. Adamič je v zvezi s tem izjavil, da akcija ni bila dobro zasnovana, saj je bila večina ameriških Slovencev republikansko usmerjena. Izrekanje podpore kralju je bilo videti kot vračanje k staremu. ${ }^{13}$ Adamič je v pismu Rooseveltu 3. februarja 1942 predlagal ustanovitev ameriške legije svobode, ki bi jo sestavljali v Afriki in Evropi zbrani vojaki. ${ }^{14}$ Vodje ameriških Slovencev so aprila 1942 izkoristili

11 Arhiv Jugoslavije (AJ), 83 Osebni arhiv Save Kosanovića, Adamič Moleku, 31. december 1941.

12 AJ, 103 Fond emigrantske vlade, Nova Jugoslavija, Poizkusni program o političnem delu, 6. avgust 1941.

13 AJ, 83 Osebni arhiv Save Kosanovića, Adamič Snoju, 15. februar 1942.

14 Franklin D. Roosevelt Memorial Library (FDRML) OF 355-A Container 3, National Defense, Adamič Rooseveltu, 3. februar 1942. 
prijateljsko srečanje ob 75-letnici rojstva Etbina Kristana, na katerem so sodelovali tudi slovenski člani jugoslovanske vlade $v$ izgnanstvu za to, da so dali pobudo za nadaljevanje skupne politične akcije $v$ prid enotni Jugoslaviji. ${ }^{15}$

Prihod kralja Petra II. konec junija 1942 na obisk v ZDA je med ameriškimi Slovenci sprožil precejšen vihar, še zlasti potem, ko so nekateri člani Ameriške slovenske zveze, ki jo je ustanovil Mally, pripravili izjavo, v kateri so izrekli dobrodošlico jugoslovanskemu monarhu. Jugoslovanska socialistična zveza je proti tej izjavi takoj protestirala. V zvezi z vsem tem so se močno poslabšali odnosi med srbskimi in hrvaškimi Američani. Da bi izboljšal odnose, je direktor Office of War Information, Elmer Davis, na Adamičevo pobudo 18. septembra 1942 sklical predstavnike ameriških jugoslovanskih izseljencev na sestanek, ki ga je vodil Allan Cranston. Na tem sestanku je 16 predstavnikov jugoslovanskih Američanov podpisalo resolucijo, v kateri so se zavezali, da bodo nasprotovali vsem poskusom, s katerimi želijo Američane jugoslovanskega porekla organizirati enega proti drugemu. Nekateri srbski predstavniki pa omenjene resolucije niso želeli podpisati. ${ }^{16}$

Na drugem sestanku, 20. oktobra 1942, so sklenili, da bodo na kongresu prebrali tri glavne referate: Vojna in ameriški Slovenci; Položaj Slovencev v Jugoslaviji zamejnih držav in Politična akcija ameriških Slovencev. Za poročevalca prvega referata so predlagali Adamiča, za drugega Etbina Kristana, za tretjega Vincenta Cainkarja. Frank Lausche, župan mesta Cleveland in po rodu Slovenec, je bil na kongres povabljen kot predstavnik ameriških oblasti. Adamič je vsem znanim slovenskim časnikom poslal javno pismo, naslovljeno na kongres, v katerem je ugotavljal položaj Slovencev v Sloveniji in zamejnih državah ter predlagal aktivno vlogo slovenskih izseljencev za izboljšanje njihovega položaja. ${ }^{77}$ Pismo je pokazalo Adamičevo dobro seznanjenost z dogodki v stari domovini. Informacije je očitno črpal iz komunističnih časopisov, kot je bil Daily Worker, pa tudi iz drugih virov odporniških gibanj v Evropi (več o tem glej Klemenčič 1987: 214-231).

\section{ADAMIČEVO DELOVANJE OD KONGRESA SANS}

Petega decembra 1942 se je $v$ Slovenskem narodnem domu v Clevelandu sestal Slovensko- ameriški narodni kongres. Za predsednika so izvolili Etbina Kristana, za častnega predsednika pa Louisa Adamiča. ${ }^{18}$ Po kongresu ameriških Slovencev se je 19. decembra 1942 v vodilnem ameriškem časniku Saturday Evening Post pojavil Adamičev znameniti članek, $v$ katerem je obsodil četnike in prikazal partizane kot edino vojskujočo silo, ki se v Jugoslaviji bori proti okupatorju. Omenjeni članek se

15 »Vsestransko priznanje Etbinu Kristanu«, Proletarec, 15. april 1942: 3.

16 Arhiv Slovenije (AS), SI AS 1590 Fond Rogelj, Allan Cranston Janku Roglju, 21. september 1942.

17 "Louis Adamič o Slovenskem kongresu«, Prosveta, 25. november 1942: 2.

18 »Slovenski narodni kongres je uspel«, Prosveta, 9. december 1942: 1-3. 
je že novembra pojavil v Cankarjevem glasniku..$^{19}$ Sodeč po odzivu je bila vsebina članka za ameriško javnost šokantna; vedno bolj so se začeli zanimati za dogajanje v Jugoslaviji. Adamič je v članku poudaril, da so vse bitke $v$ Jugoslaviji, kjer naj bi padlo tudi do 100 nemških vojakov, v resnici izbojevali partizani in ne četniki Draže Mihailovića, kot so do takrat verjeli ameriški bralci časopisov. Do konca leta 1942 so ameriške časopise polnile zgodbe o junaštvih četnikov in Draže Mihailovića. ${ }^{20} \mathrm{Na}$ začetku leta 1941 je k temu največ pripomogla ameriška udeleženka vojne v Jugoslaviji, Ruth Mitchel, ki je v medijih pomagala širiti zgodbo o Mihailovićevi predanosti v borbi proti silam osi. ${ }^{21}$ Rušenje Mihailovićeve slave je bila izjemno težka naloga, ki se ni mogla zgoditi brez sodelovanja predstavnikov oblasti. Adamiču je pri utrjevanju njegove zgodbe pomagal takratni newyorški župan La Guardia, ki je osmešil Ruth Mitchel in podprl partizane (Lees 2007: 111). ${ }^{22}$

Petnajstega januarja 1943 je Adamič organiziral sprejem predstavnikov Slovenskega ameriškega narodnega sveta pri Sumnerju Wellsu, ameriškem državnem podsekretarju. Na tem sestanku so se Adamič in katoliški del z Zakrajškom v SANS-u dokončno razšli, ker naj bi slednji želeli skupaj z ministrom Snojem pred Američani prikriti dejstvo, da je del Slovencev v stari domovini dobil orožje od Italijanov, da bi se lahko branili pred partizani oziroma komunisti, kakor so jih imenovali (Klemenčič 1981: 1061). Adamič je namesto tega Wellsu raje poudaril, da je Slovenija majhna deželica s približno dva milijona prebivalci, ki so ostali razdeljeni med štiri države. Delegacija na čelu z Adamičem je Wellsu na koncu izročila spomenico, $v$ kateri je zapisala, da je velik del Slovencev zaradi krivičnih mednarodnih sporazumov po letu 1918 postal neprostovoljna manjšina, razdeljena med Italijo, Avstrijo in Madžarsko. Nato so poudarili, da je upor Slovencev in Slovenije proti silam osi pomembno dejanje, ki ovira nemške vojne transporte na poti iz Italije v Sovjetsko zvezo. Tako so želeli poudariti slovenski vojaški prispevek v zavezniški borbi proti fašizmu in nacizmu. Poudarili so željo Slovencev po združeni Sloveniji, ki bi imela široko avtonomijo in bi ostala del svobodne federativne in demokratične Jugoslavije. Vendar se je organizacija zaradi političnih nesoglasij že takoj na začetku znašla pred razkolom. ${ }^{23}$

Devetnajstega junija 1943 so predstavniki ameriških Slovencev, Hrvatov in Srbov Adamiču poslali telegram s sporočilom, da so ustanovili Združeni odbor

19 Adamic, Louis, »Adamič v 'Saturday Evening Post«", Enakopravnost, 21. december 1942: 1; Adamič, Louis, »Louis Adamič: Partizani in Mihajlović“", Cankarjev glasnik 4, november 1942: 95-106.

20 »Yugoslavs Taking Heavy Toll of Foe«, The New York Times, 23. julij 1942: 5.

21 Lengyel, Emil, »Report on the Balkans«, The New York Times, 17. oktober 1943: 83.

22 AJ, 83 Osebni arhiv Save Kosanovića, Kosanović La Guardia, 3. september 1942; Narodna univerzitetna knjižnica Ljubljana (NUK), Ms 1858 Adamičeva zapuščina, Adamič Kristanu, 21. december 1942; AS, SI AS 1241 Fond SANS, Zapisnik seje SANS, 22. december 1942.

23 AS, SI AS 1241 Fond SANS, šk. 3, Memorandum Subbmitted to the Department of State, Friday, January 15, 1943, by the Delegation of the Slovenian American National Council, Representing Americans of Slovene Extraction; Prav tam, Introduction by Louis Adamic. 
jugoslovanskih Američanov (ZOJSA) in ga izvolili za svojega prvega predsednika. ${ }^{24}$ Istega leta v juliju je bil v Detroitu bolgarsko-makedonski kongres. Ta se je pridružil Združenemu odboru jugoslovanskih Američanov, ki je tako postal Združeni odbor južnoslovanskih Američanov (ZOJSA). Sedmega avgusta 1943 je Adamič sklical sejo ZOJSA, na katero je povabil Frana Petrinovića, ki je v odboru predstavljal Jugoslovane iz Južne Amerike, kakor tudi enega najbogatejših jugoslovanskih Američanov, Hrvata iz Kalifornije, Martina Bogdanovića. Clevelandski župan Frank Lausche pa se vabilu ni odzval, saj naj bi izjavil, da Združeni odbor ne predstavlja mnenja vseh južnoslovanskih Američanov. ${ }^{25}$ Tako so na površje začeli prihajati resnejši politični nesporazumi med slovenskimi izseljenci v ZDA (Klemenčič 1987: 234-235).

$V$ tem času se je Adamiču porodila ideja, da bi lahko svoja opažanja in poglede na dogajanja v Jugoslaviji predstavil v svoji novi knjigi, ki jo je naslovil My Native Land oziroma Moja rojstna dežela. V knjigi, ki je izšla leta 1943, v času, ko so v Jugoslaviji potekali najhujši boji proti silam osi, se je Adamič samoiniciativno podal v svojo osebno vojno proti vplivu »Mihailovićeve legende«, ki je prevladovala v ameriškem javnem tisku. ${ }^{26}$ Mihailovića so na začetku vojne kot legendarnega voditelja upornikov prikazovali celo v ameriškem komunističnem glasilu Daily Worker. ${ }^{27}$ Adamič se je zato od decembra 1942 trudil prikazati četnike kot predstavnike prejšnjega režima, ki so se z namenom ohranjanja starih privilegijev $v$ vojni držali bolj po strani. Namesto njih so pravo vojno vodili Titovi partizani, predstavniki novega reda in družbenih sprememb, ki jih je Jugoslavija nujno potrebovala ${ }^{28}$ (Klemenčič 1987: 238; Adamič 1981: 68). Zaradi tega je prišlo do reakcije katoliškega tabora. Zveza slovenskih župnij je poskušala izpeljati pravo križarsko vojno proti Adamiču in njegovi knjigi $\mathrm{My} \mathrm{Na-}$ tive Land. Pomožna akcija slovenskih župnij je septembra 1943 na svoji seji sklenila pripraviti protestno zborovanje zoper Adamičevo knjigo. Napisali so tudi protestno pismo in ga razposlali na različne naslove $v$ ZDA, vendar brez posebnega uspeha. ${ }^{29}$

Adamič je na svojem prvem javnem shodu SANS-a konec leta 1943, ki se ga je udeležilo okrog 1.200 slovenskih poslušalcev, spregovoril v slovenščini in med drugim jasno predstavil svoje stališče o jugoslovanski vladi v izgnanstvu. O njej je zapisal: »Jaz sem proti tisti vladi - proti tistemu kraljevskemu pobalinu, ki vleče pol milijona dolarjev iz jugoslovanske kase, proti Fotiću [...], ki so vsi proti Jugoslaviji in proti Rusiji, in katerih Slovenija sploh ne zanima. Jaz sem za to, da cela vlada v izgnanstvu ostane stalno - za zmeraj - v izgnanstvu ....110

24 US National Archives (Suitland Maryland), R.G. 226 Records of the Office of Strategic Services 37796 , Foreign Nationality Grups in the United States, Memorandum by Foreign Nationalities Branch to the Director of Strategic Services, No. B-52, 29. 6. 1943. NUK, Ms 1858 Adamičeva zapuščina, Lausche Adamiču, 3. avgust 1943.

26 Brock, Ray, »Either They Die or We Do«, The New York Times, 1. februar 1942: 138.

27 »Night and Day Slav Partisans Hit Back«, Daily Worker, 5. julij 1942: 2.

28 »Komentarji «, Proletarec, 8. december 1943: 4.

29 AS, SI AS 1660 Osebni fond Izidorja Cankarja, Zapisnik seje Zveze slovenskih župnij, 8. 9. 1943.

30 „Govor pisatelja Louisa Adamiča na shodu SANSa v Clevelandu«, Enakopravnost, 17. november 1943: 1. 
Ameriška vojska je že leta 1942 ponatisnila in med svoje vojake razdelila okoli 50.000 izvodov Adamičeve knjige The Natives Return. Ameriški kongresnik George A. Dondero, republikanec iz Michigana, je ostro kritiziral vojno ministrstvo in avtorja knjige obtožil za »komunističnega sopotnika«. Knjiga naj bi po njegovem mnenju vsebovala »komunistično propagando«. ${ }^{31}$ Podobnega mnenja je bil kongresnik Fred E. Busbey, republikanec iz Illinoisa. Ta je hkrati sedel v komisiji, ki je preiskovala neameriške aktivnosti v ZDA in se je v zgodovino zapisala kot Diesova komisija. Busbey je Adamiča označil za bolj nevarnega od samega generalnega sekretarja ameriške Komunistične partije, Earla Browderja. K temu mnenju je gotovo pripomogla tudi brošura Shall Slovenia be Sovietized, ki jo je izdala in natisnila Zveza slovenskih župnij. ${ }^{32}$ Prav v zvezi s ponatisom omenjene knjige, ko so se v ameriškem tisku začele pojavljati polemike o tem, zakaj zavezniki pomagajo četnikom namesto partizanom, se je Adamič na prvi pogled izkazal kot vodilna osebnost v ZDA, ki namensko propagira komunizem, partizane in Tita. ${ }^{33}$

FBI-jeva poročila so sicer polna določenih netočnosti, kot na primer navedba, da se pred vojno Adamič nikoli ni ukvarjal s problematiko Jugoslavije, kar je glede na njegove knjige in članke, ki jih je napisal in z njimi zaslovel, povsem netočno in neresnično. Anonimni informator je špekuliral tudi o tem, ali je Adamič mogoče širil komunistično propagando, ker naj bi upal na kakšno povojno diplomatsko zaposlitev? V primeru »sovjetizacije Balkana« bi Adamič lahko postal glavni sogovornik in svetovalec ameriški vladi. V FBI-jevih poročilih, ki so jih naslavljali na direktorja Hooverja, so tudi podrobni opisi Adamičevih poti in poznanstev, kje in s kom se je družil. FBI je v hotelu, kjer so se dobivali člani ZOJSA, nastavil prisluškovalne naprave. Več o uspehih prisluškovanja dokumenti ne navajajo. ${ }^{34}$ Veliko se je špekuliralo tudi okoli vprašanja, ali je bil Adamič komunist ali zgolj oportunist? Dokumenti so pokazali, da je FBI okarakteriziral vse Adamičeve organizacije, v katerih je sodeloval, kot komunistične frontne organizacije, vključno z Združenim odborom južnoslovanskih Američanov. ${ }^{35}$

SANS se je na svoji redni konvenciji sešel 3. septembra 1944 v Clevelandu, kjer so poročali o dejavnosti sveta $v$ zvezi s priznanjem partizanov kot edine legitimne sile, ki se je borila proti okupatorju. Šestindvajsetega maja 1944 je Adamič poslal pismo predsedniku Rooseveltu, v katerem ga je pozval, naj prizna Narodni komite osvoboditve Jugoslavije (NKOJ) pod vodstvom maršala Tita, ki je predstavljal začasno vlado Jugoslavije. Na pismo je pozitivno odgovoril takratni državni sekretar James Byrnes. ${ }^{36}$

31 »Kdo je kongresnik George A. Dondero?«, Enakopravnost, 20. december 1943: 2; »Kongresnik napadel pisatelja Adamiča«, Prosveta, 13. december 1943: 1.

32 »Komentarji«, Proletarec, 9. februar 1944: 4.

33 Immigration History Research Center Archives (IHRCA), 1330 Lorraine M. Lees collection of FBI files on Yugoslav American Ethnic Organizations, Box 6, The United Committee of South-Slavic Americans, 27. november 1943.

34 Prav tam, Memorandum for M.D. Ladd in FBI Teletype. Memorandum for D.M. Laddan, 7. januar 1944.

35 Prav tam, The United Committee of South-Slavic Americans, 27. november 1943.

36 FDRML, OF 364-A, Container 3, Yugoslavia Misc, Adamič Rooseveltu, 26. junij 1944. 
Že omenjeni dokumenti FBI, ki so bili glavni vir za knjigo Lorraine Lees, prikazujejo stališča ameriških obveščevalnih služb do Adamičevega delovanja med drugo svetovno vojno. Iz dostopnih dokumentov je razvidno, da gre za površne karakteristike tako Louisa Adamiča kot tudi preostalih vodilnih članov ZOJSA in posameznih organizacij, v katerih so imeli vodilni predstavniki izseljencev svojo pomembno vlogo. Direktor FBI Hoover se je začel osebno zanimati za delovanje Louisa Adamiča takoj po njegovem imenovanju za predsednika ZOJSA. ${ }^{37}$ Svojim agentom na terenu je naročil, naj izpeljejo tajno preiskavo, na podlagi katere bi lahko izvedeli, kdo jih financira oziroma kako se financirajo južnoslovanske izseljenske organizacije v ZDA? ${ }^{38}$ Hoover je verjel, da je omenjena organizacija samo krinka za komunistično delovanje $v$ ZDA. Tako iz dokumentov lahko razberemo podrobne analize Adamičevih političnih stališč, ki jih je javno izražal na shodih ali v člankih, in njihovo vzporejanje s stališči komunističnega časnika Daily Worker. Tako so želeli prikazati Adamiča kot »komunističnega sopotnika«. ${ }^{39}$

Podrobnejša analiza FBI-jevih dokumentov in poročila njihovih anonimnih informatorjev kažejo, da so agenti radi pritrjevali svojemu šefu, da je Adamič v ZDA vodil komunistično propagando, čeprav ga niso označevali za komunista. Omenjena dejanja naj bi počel iz koristoljubja. Tukaj se je namigovalo na njegove tuje vire financiranja, ki pa jih nikoli niso dokazali. FBI je bil prepričan, da Adamiča bolj kot ideologija spodbuja denar. Po drugi strani FBI-jevi dokumenti razkrivajo zanimivo razmišljanje obveščevalnih služb, ki so želele okarakterizirati Adamičevo kompleksno osebnost. Označili so ga za propagandista, oportunista in ambicioznega povzpetnika, ki samega sebe promovira, da bi laže prodajal svoje knjige. Veliko pozornost so posvetili njegovemu zagovarjanju Rusije oziroma »sovjetizacije Jugoslavije«. Najbolj zanimiva navedba FBI-ja je bila domneva, da naj bi Adamič svojo knjigo My Native Land napisal s pomočjo ruskih člankov, ki so jih v ZDA komunistični somišljeniki pretihotapili na ladjah; te naj bi bile na podlagi Zakona o posojilu in najemu namenjene $v$ Sovjetsko zvezo. Ladje naj bi se vračale $s$ tajnimi navodili in članki, ki jih je Adamič potreboval za pisanje knjige. Seveda so bile takšne in podobne zgodbe le plod domišljije posameznih agentov, njihove domneve in poročila so bila namreč brez konkretnih dokazov. ${ }^{40}$

Ko je med ameriškimi Slovenci leta 1944 do razdora prišlo zaradi podpore partizanom in Rusiji, lahko v FBI-jevih dokumentih zasledimo dokaj podrobne ocene takratnega stanja med izseljenci. V FBI so bili prepričani, da Adamiču ne bo uspelo vplivati na izseljenske organizacije, saj je med njimi 85 odstotkov vernih katoličanov,

37 IHRCA, 1330 Lorraine M. Lees collection of FBI files on Yugoslav American Ethnic Organizations, United Committee of South-Slavic Americans, 13. avgust 1943.

38 Prav tam.

39 Prav tam, US-Yugoslavs Form United Committee in War Body, United Committee of South-Slavic Americans Representing Croatians, Serbians, Slovenians, Bulgarians and Macedonians Organized in U. 24. avgust 1943.

40 Prav tam, The United Committee of South-Slavic Americans, 27. november 1943. 
ki se ne bodo prepustili vplivu komunistične propagande. Omenjalo se je tudi, da ima Adamič prevelik vpliv na določene visoke vladne uradnike, kar naj bi mu dajalo lažno avtoriteto med ameriškimi Slovenci. Med dokumenti so številna namigovanja o njegovih političnih nagnjenih in predvsem sledenju agentov, kje in kdaj se je dobil s kakšnim znanim ameriškim komunistom. FBI je bil takrat obseden z okarakteriziranjem in iskanjem prikritih komunistov, kar je bil uvod v povojni makartizem. ${ }^{41}$

Zgodba o domnevni Adamičevi komunistični preteklosti je seveda neresnična. Že Hooverjev agent, ki je pisal karakteristike, je v enem od poročil pravilno zapisal, da je Adamič »preveč pameten, da bi bil član komunistične partije «. ${ }^{42}$ Adamič je osebno zavračal ideološko razmišljanje in se je zato leta 1926 tudi umaknil iz ameriške socialistične stranke (Klemenčič 1981: 1054). Vedno je zanikal članstvo $v$ katerikoli politični stranki, razen Progresivni stranki, s katero je sodeloval v predsedniški kampanji leta 1948. Dejansko je bil kratek čas član socialistične stranke, zapustil pa jo je iz prepričanja, da je »razširjanje socialističnih idej med ameriškim delavstvom vredno toliko kot pljuvanje v ocean z namenom, da bi razširili njegov obseg «. ${ }^{43}$

Progresivna stranka je bila ustanovljena posebej za predsedniške volitve $v$ ZDA leta 1948, kjer je na njeni listi kandidiral nekdanji podpredsednik ZDA, Henry Wallace. Nastanek tretje stranke so spodbudili sovjetski komunisti. O tem podrobneje piše Thomas Devine v svoji knjigi o Wallaceovi predsedniški kampanji leta 1948 in nasploh o prihodnosti povojnega ameriškega liberalizma, s katerim je bil povezan tudi Adamič. Wallace seveda ni bil niti komunist niti simpatizer komunističnih idej. Vendarle so ameriški komunisti na željo sovjetskih tovarišev pomagali vzpodbujati Wallaceovo predsedniško kampanjo, da bi tako ogrozili položaj Harryja Trumana. Predsedniška tekma se je končala s prepričljivo Trumanovo zmago. Če sta bila Adamič in Wallace na začetku vesela sodelovanja ameriških komunistov, sta se pozneje od njih distancirala, pa tudi eden od drugega. Adamič je poskušal Wallacea odvrniti od tesnega sodelovanja $z$ ameriškimi komunisti. Prepričal ga je, da je edini interes ameriške KP v predvolilni kampanji ta, da bi po predsedniških volitvah, $v$ katerih bo Wallace poražen, pridobila čim več članov Progresivne stranke (Žitnik 1995b: 20). Adamič je veliko prej od Wallacea spoznal pasti sodelovanja ameriških komunistov $v$ kampanji, zato je kot simpatizer jugoslovanskih komunistov $v$ informbirojevski krizi stopil na stran Jugoslovanov in podprl Tita ${ }^{44}$ (Devine 2013: 25-34).

41 Prav tam, The United Committee of South-Slavic Americans, 3. april 1944; The United Committe of South-Slavic Americans, 2. maj 1944.

42 Prav tam, The United Committee of South-Slavic Americans, 27. november 1943.

43 Adamic, Louis, »Now, What about Communism?«, Trends \& Tides, julij-september 1948: 13-16; Chicago Historical Society, Molek papers, Adamič Moleku, 9. marec 1925.

44 Adamic, Louis, »Cominform and Yugoslavia«, Trends \& Tides, julij-september 1948: 8. 


\section{ZAKLJUČEK}

Adamičevo delovanje $v$ ZDA med drugo svetovno vojno je močno vplivalo na ameriško javno mnenje in njegov odnos do Jugoslavije in nasploh do komunistov. $\mathrm{Na}$ preprost način jim je znal približati zgodbo svoje stare domovine, da so Američani na koncu podprli partizane in Titovo vlado. Zaradi tega je seveda takoj po vojni padel v nemilost, kar ga je potisnilo v veliko osebno stisko. Zgodbo o Louisu Adamiču bi na tem mestu rada končala z njegovo smrtjo leta 1951. Čeprav krožijo o njegovi smrti najrazličnejše zgodbe in špekulacije, ki namigujejo na njegov uprizorjeni umor in samomor, imamo na razpolago dokument $\mathrm{FBl}$, datiran $\mathrm{z}$ dnem njegove smrti, 3. septembrom 1951, kjer je ročno navedeno, kdo naj bi ubil Adamiča, vendar pa je $v$ tem dokumentu njegova identiteta prikrita. Na omenjenem dokumentu je prikrita tudi identiteta poročevalca. Po drugi strani podpisani Matjaž Klemenčič hranim pričevanje pokojnega kongresnika Johna Blatnika, ki je bil takrat, ko so preiskovalci opravljali balistično preiskavo, ki je odkrila dve krogli v njegovi glavi, skupaj z Jankom Rogljem, predsednikom Ameriške bratske zveze, na Adamičevi farmi. To pričevanje naj bi dokazovalo, da sprožilca sam ni mogel sprožiti dvakrat. Treba je tudi povedati, da je bil Adamič proti koncu življenja v osebni stiski in živčno razrvan, sploh v času, ko so ga ubili. Tudi če zgodba o njegovem umoru ne drži, velja poudariti dejstvo, da je FBI s pomočjo raznih pritiskov že prej ustvaril razmere, da bi Adamič lahko storil samomor. Tako ostaja Adamičeva smrt še naprej nerazrešena uganka, njegov pečat na slovensko in ameriško historiografijo pa velik.

\section{LITERATURA}

Adamic, Louis (1941). Two-way Passage. New York, London: Harper \& Brothers. Adamič, Louis (1981). Moja rojstna dežela. Ljubljana: Založba Borec.

Christian, Henry (1971). Louis Adamic: A Checklist. Kent, OH: Kent State University Press. Christian, Henry (1981). Izbrana pisma Louisa Adamiča. Ljubljana: Cankarjeva založba. Devine, Thomas W. (2013). Henry Wallace's 1948 Presidential Campaign and the Future of Postwar Liberalism. Chapell Hill: University of North Carolina Press.

Friš, Darko (1995). Korespondenca Kazimirja Zakrajška O.F.M. (1928-1958). Viri 8.

Friš, Darko (2001). Ameriški Slovenci in leto 1941. Prispevki za novejšo zgodovino XLI/2, 267-280.

Fotitch, Constantin (1948). The War we Lost: Yugoslavia's Tragedy and the Failure of the West. New York: Wiking Press.

Hazemali, David, Matjašič Friš, Mateja (2018). »Naši simpatizerji Avstrije so bili utišani kot z nabojem «: Položaj slovenske skupnosti v Združenih državah Amerike v času prve svetovne vojne. Acta Histriae 26, 899-922.

Hudomalj, Andrej (2004). Ministrovanje ministra Franca Snoja. Arhivi 27/1, 121-130. 
Jeffreys Jones, Rhodri (2007). The FBI: A history. New Haven, London: Yale University Press.

Klemenčič, Matjaž (1981). Politično delo Louisa Adamiča. Teorija in praksa 18/9, 1054-1068.

Klemenčič, Matjaž (1987). Ameriški Slovenci in NOB v Jugoslaviji. Maribor: Založba Obzorja.

Klemenčič, Matjaž, Šeruga, Tadej (2019). Pregled zgodovine slovenske skupnosti v Elyju, Minnesota. Maribor: Univerza v Mariboru.

Klemenčič, Matjaž (2011). The Reactions of Immigrants from the South Slavic Lands and their Descendants in the USA to the Dissolution of Yugoslavia (1989-1993). Dve domovini / Two Homelands 33, 37-53.

Lees, Lorraine M. (2007). Yugoslav-Americans and National Security during World War II. Chicago: University of Illinois Press.

Novak, Bogdan C. (1994). Adamic and Yugoslavia During World War II. Dve domovini /Two Homelands 5, 63-84.

Novak, Bogdan C. (1998). Louis Adamic's Work for the Official Recognition of Tito and the National Liberation Movement of Yugoslavia by the United States Government. Dve domovini / Two Homelands 9, 67-83.

Novak, Bogdan C. (2004). Pater Kazimir Zakrajšek. Ljubljana: Družina.

Shiffman, Dan (2005). Korenine multikulturalizma: Delo Louisa Adamiča. Ljubljana: Založba ZRC.

Stanonik, Janez (ur.) (1981). Louis Adamič simpozij. Univerza Edvarda Kardelja v Ljubljani.

Zakrajšek, Kazimir (1942). Ko smo šli v morje bridkosti. Washington D.C.: Univerza v Kaliforniji.

Žitnik, Janja (1992). Louis Adamič in sodobniki: 1948-1951. Ljubljana: SAZU.

Žitnik, Janja (1993). Pero in politika: Zadnja leta Louisa Adamiča. Ljubljana: Slovenska matica.

Žitnik, Janja (1995a). Orel in korenine med »brušenjem« in cenzuro. Ljubljana: Znanstvenoraziskovalni center SAZU.

Žitnik, Janja (1995b). Pogovori o Louisu Adamiču. Ljubljana: Prešernova družba.

\section{ARHIVSKI VIRI}

Arhiv Jugoslavije (AJ), 83 Osebni arhiv Save Kosanovića, fasc. 15.

Arhiv Jugoslavije (AJ), 103 Fond emigrantske vlade, fasc. 6.

Arhiv Slovenije (AS), SI AS 1241 Fond SANS, šk. 3, 11.

Arhiv Slovenije (AS), SI AS 1590 Fond Rogelj, šk. 3.

Arhiv Slovenije (AS), SI AS 1660 Osebni fond Izidorja Cankarja.

Chicago Historical Society, Molek papers, šk. 1. 
Franklin D. Roosevelt, Memorial Library, Hyde Park, New York (FDRML), OF 355-A Container 3. OF 364-A.

Immigration History Research Center Archives (IHRCA), 1330 Lorraine M. Lees collection of FBI files on Yugoslav American Ethnic Organizations.

Narodna univerzitetna knjižnica Ljubljana (NUK), Ms 1858 Adamičeva zapuščina.

US National Archives (Suitland Maryland), R.G. 226 Records of the Office of Strategic Services 37796, Foreign Nationality Grups in the United States.

\section{ČASOPISNI VIRI}

The Saturday Evening Post, 1942.

Trends \& Tides, 1948.

Delo, 1981.

Nova doba, 1939-1940.

Prosveta, 1941-1943.

Enakopravnost, 1941-1943.

Amerikanski Slovenec, 1941.

Proletarec, 1942-1944.

Cankarjev glasnik, 1942.

The New York Times, 1942, 1943.

Daily Worker, 1942. 


\section{SUMMARY}

\section{LOUIS ADAMIC AND THE SECOND WORLD WAR IN AMERICAN AND SLOVENIAN HISTORIOGRAPHY Matjaž KLEMENČIČ, Milan MRĐENOVIĆ}

In the article, the authors present a new perspective on Louis Adamic's role during the Second World War, especially in the light of contemporary historiography. Adamic's political and publicist activity in the United States undoubtedly increased the likelihood of the official recognition of Tito's Yugoslavia by the US. It also helped raise sympathy for the Partisans instead of the Chetniks, who were presented in his writings as occupying collaborators. To date, historiographies in the US and Slovenia have not been particularly concerned with the views of the US security services on Adamic's political activity Recent US literature has devoted much more attention to this issue. Newly accessible documents also provide researchers with a better overview and a wealth of new research material. The interpretation of Adamic's role during the Second World War in Slovenia must be understood through the distinction between two periods: before and after 1991. After 1991, researchers began to deal with Adamic's legacy more critically. Adamic was an extremely complex personality. Although he was sympathetic to liberal and leftist views, he believed in the American ideals of freedom and democracy. He also epitomizes the story of a successful and outgoing critically-minded immigrant who paved his way to success through hard work and effort, with the help of a free press. However, for Adamic, part of the "American dream" meant that he could be critical of capitalist society, consumerism and American foreign policy in general, as well as the US's "melting pot" policy. Through his criticism, he wanted to encourage important processes that could have improved the situation of immigrants, workers, and other marginalized groups in American society. Because of this, he was closely monitored by the US security services (FBI) during the Second World War. In the article, the authors also discuss how the FBI followed Adamic during the war and assessed his actions, thoughts and tactics. Most of them were mistaken in their assessments, especially of Adamic's complex personality. Adamic was regarded as a "communist fellow traveler", although he was never a member of the Communist Party, nor did he share their beliefs. He supported the efforts of the Yugoslav partisans and Yugoslav communists for pragmatic reasons because he believed that they were the only political force capable of realizing the idea of the creation of federal Yugoslavia, which Adamic also advocated. The authors conclude their article with the issue of Adamic's untimely death. 